\title{
HISTOPATHOLOGICAL ALTERATIONS ON ANTARCTIC FISH Notothenia coriiceps AND Notothenia rossii AS BIOMARKERS OF AQUATIC CONTAMINATION \\ http://dx.doi.org/10.4322/apa.2014.078
}

\author{
Lucélia Donatti1,*, Flávia Sant'Anna Rios¹, Cintia Machado', Maria Rosa Demengeon Pedreiro', \\ Priscila Krebsbach ${ }^{1}$, Claudio Adriano Piechnik', Tânia Zaleski', Mariana Forgati', \\ Luciana Badeluk Cettina ${ }^{1}$, Flavia Baduy Vaz da Silva ${ }^{1}, N^{2}$ adia Sabchuk¹, Cleoni dos Santos Carvalho², \\ Edson Rodrigues ${ }^{3}$, Edson Rodrigues Junior ${ }^{1,3}$, Mariana Feijó de Oliveira ${ }^{1,3}$ \\ 'Laboratório de Biologia Adaptativa, Departamento de Biologia Celular, Universidade Federal do Paraná - UFPR, \\ Rua Coronel Francisco Heraclito dos Santos, 210, Centro Politécnico, CEP 81531-970, Curitiba, PR, Brazil \\ 2Universidade Federal de São Carlos - UFSCar, Campus Sorocaba, \\ Rod. João Leme dos Santos, Km 110, SP-264, CEP 18052-780, Sorocaba, SP, Brazil \\ ${ }^{3}$ Departamento de Biologia, Instituto Básico de Biociências, Universidade de Taubaté - UNITAU, \\ Campus do Bom Conselho, Rua 04 de Março, 432, CEP 12020-270, Taubaté, SP, Brazil \\ *e-mail: donatti@ufpr.br
}

\begin{abstract}
The Antarctic continent is considered one of the most well preserved areas of the planet; however, human occupation of this environment, for research purposes, generates impacts on the ecosystem, especially near scientific stations. Studies on structural alterations, mainly of the liver and gills of fish are an important source of information of environmental toxicity. This work intended to evaluate histopathologically, the livers and gills of the Antarctic fish species Notothenia coriiceps and Notothenia rossii captured in Admiralty Bay, where the Comandante Ferraz Brasilian Antarctica Station is located. Histological and ultrastructure techniques were employed. The only liver diseases found were necroses and hyperplasia, aneurysm and branchial detachment were the diseases found on the gills. The occurrence of alterations, both in the liver and gills, was low and punctual, although with higher incidence in the N. coriiceps than N. rossii. It can be concluded that the low alteration occurrence rate, does not affect the functionality of the analyzed organs, as it presents no lethality to the species.
\end{abstract}

Keywords: Antarctic nototenidae, gills, liver, aquatic contamination

\section{Introduction}

Studies reporting human activity in the Admiralty Bay date back to 1987, with the beginning of the analyzes of hydrocarbon concentrations in sediments and on the water surface (Bícego et al., 1996; Oliveira et al., 2007; Martins et al., 2010). The research about distribution and concentration patterns of waste indicators deriving from the station in soil samples (Montone et al., 2010), the biomonitoring of genotoxic potential through nuclear erythrocyte abnormalities (Ngan et al., 2007) and the evaluation of heavy metal concentration (Santos et al., 2006) are examples of well-studied cases.
Histopathological and ultrastructure analyses are excellent methodological tools in studies of environmental biomonitoring with the fish as a biological model. Damage detected in cells, tissues or organs exposed to polluting agents represent an integration of cumulative effects of these substances in a physical and biochemical manner (Myers \& Fournie, 2002).

This work has the objective to evaluate, from a histological and ultrastructure aspect, the health of Antarctic fish Notothenia rossii and Nototehnia coriiceps, collected in different points of the Admiralty Bay - King George Island South Shetlands Archipelago, Antarctic Peninsula.

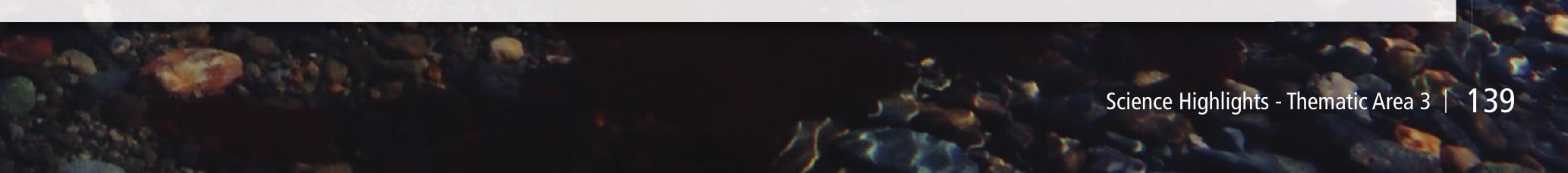




\section{Materials and Methods}

In Admiralty Bay, the Antarctic fish species Notothenia coriiceps $(\mathrm{n}=36)$ and Notothenia rossii $(\mathrm{n}=26)$ were collected with line and hook at depths ranging from 10 to 25 meters and sacrificed, according to the Committee of Animal Experimentation-UFPR n${ }^{\circ} 46$. Five sampling stations were established: Comandante Ferraz Antarctica Station (EACF) (62 04' 59,3" S and 58 23' 23" W); Punta Plaza (PP) (62 $05^{\prime} 26,9^{\prime \prime}$ S and $\left.58^{\circ} 24^{\prime} 11,9^{\prime \prime}\right)$; Arctowski, in front of the Ecology Glacier (ECO) (62 ${ }^{\circ} 10^{\prime} 03,5^{\prime \prime} \mathrm{S}$ and $58^{\circ}$ $\left.26^{\prime} 59,8^{\prime \prime}\right)$; Botany Point (BO) (62 $06^{\circ} 15,7^{\prime \prime} \mathrm{S}$ and $58^{\circ} 21^{\prime}$ $\left.14,0^{\prime \prime}\right)$ and Refúgio 2 (R2) (62 $04^{\circ} 14,5^{\prime \prime}$ e $\left.58^{\circ} 25^{\prime} 16,5^{\prime \prime} \mathrm{W}\right)$.

For the light microscopic analysis (MO), liver and gills were fixed in ALFAC, included in Paraplast Plus ${ }^{\circledR}$ and stained with haematoxylin and eosin (H.E) (Clark, 1981). For electronic microscopy the gills and liver were fixed in Karnovsky (1965). The analyses and documentation of the material were made using an electronic transmission microscope JEOL 1200EX II. The liver and branchial histopathologies were analysed and identified according to Mallat (1985), Roberts (1989), Brasileiro-Filho (1994). The lesions were quantified according to Bernet's index (Bernet et al., 1999).

\section{Results}

Histologically, the liver and branchial tissue of the $N$. coriiceps and $N$. rossii follow the pattern described in literature. The liver is constituted of cells called hepatocytes and liver parenchyma (Figure 2) while the branchial strand is made of a primary lamella, which in turn is made of two rows of breathing or secondary lamellas (Table 1; Figure 2).

Necrosis was the only liver alteration found and just in $N$. corriceps (20\% BO, 25\% EACF and $7.7 \%$ of the fish captured showed the lesion), while branchial detachment, aneurysm and hyperplasia were found in the gills of both species (Table 1; Figure 2). Analyzing the sampling stations and species collected, the occurrence of histopathologies was punctual and only affected a small number of animals. On the $N$. coriiceps a slightly higher occurrence rate was noted (Figure 1). The averages of the lesions indicated by Bernet's Index in each sampling station and each species are shown in Figure 1, suggesting that the highest values for $N$. coriiceps indicate that the species is more sensitive.

\section{Discussion}

Studies report that Antarctica has been affected for some time by sporadic pollution events, generated by the intensity and variety of human activities, which have increased over recent years (Oliveira et al., 2007; Tin, 2008). The branchial detachment or edema was one histopathology found in all collected animals, regardless of the species or sampling

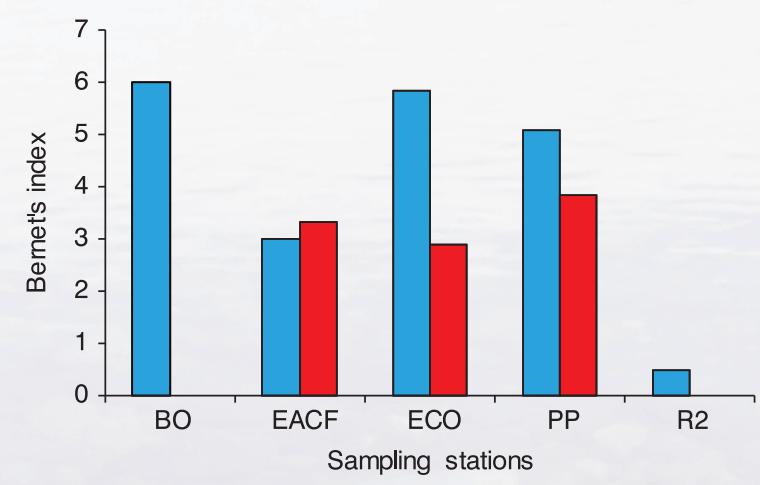

Figure 1. Average of Bernet's Index (alterations in the gills and liver) for each sampling collection and species. Notothenia coriiceps: Columns filled and Notothenia rossii: Empty columns. $\mathrm{BO}=$ Botany; EACF = Comandante Ferraz Brazilian Antarctica Station; ECO = Ecology; PP = Punta Plaza and R2 = Refúgio 2 .

Table 1. Percentage of Nothotenia coriiceps (NC) and Nothotenia rossii (NR) gill lesions in each of the sampling station measured. BO = Botany; $\mathrm{EACF}=$ Comandante Ferraz Brazilian Antarctica Station; ECO = Ecology; PP = Punta Plaza and R2 = Refúgio 2.

\begin{tabular}{|c|c|c|c|c|c|c|}
\hline \multirow[b]{2}{*}{ Collection sampling } & \multicolumn{2}{|c|}{ Detachment } & \multicolumn{2}{|c|}{ Aneurysm } & \multicolumn{2}{|c|}{ Hyperplasia } \\
\hline & NC & NR & NC & NR & NC & NR \\
\hline $\mathrm{BO}$ & 80,0 & - & 40,0 & - & 60,0 & \\
\hline EACF & 75,0 & 100,0 & 0,0 & 0,0 & 0,0 & 33,3 \\
\hline ECO & 100,0 & 100,0 & 25,0 & 0,0 & 83,3 & 22,2 \\
\hline PP & 80,0 & 100,0 & 0,0 & 8,3 & 100,0 & 41,7 \\
\hline $\mathrm{R} 2$ & 33,0 & 0,0 & 0,0 & 0,0 & 0,0 & 0,0 \\
\hline
\end{tabular}




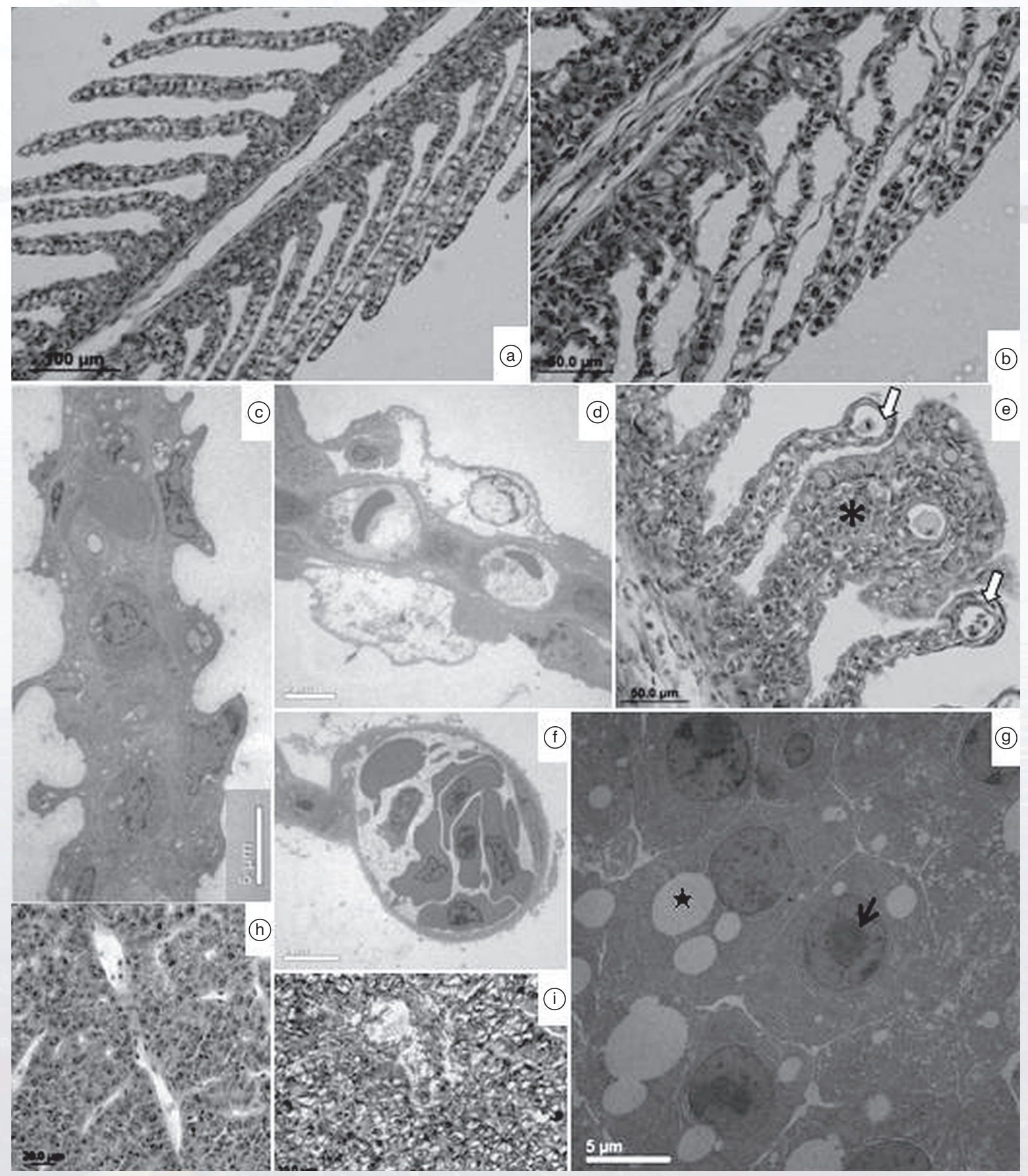

Figure 2. Light microscopic ( $a, b, e, h$ and i) and electron micrograph (c, d and g) of liver ( $g$ to i) and branchial (a to f) of $N$. coriiceps (c, $d$, e, $f$ and i) and N. rossii ( $\mathrm{a}, \mathrm{b}, \mathrm{g}$ and h). a) Cross-sections through the normal lamellae and detail in c; b) Branchial detachment and detail in d; e) Hyperplasia (*) and aneurysm $(\Rightarrow)$. f) Detail of aneurysm. h) Cross-sections through the liver and detail in g) $(\rightarrow)$ nucleolus; ( $\star$ ) lipid droplets. i) Necrosis. 
stations. This alteration acts as a defensive mechanism, decreasing the superficial area of the gills, and increasing the spreading distance to the harmful agent (Thophon et al., 2003). Aneurysm was found only one N. rossi and five $N$. coriiceps, and for Van den Heuvel et al. (2000), this damage leads to death of the pillar cells, causing accumulation of blood cells in the region. Hyperplasia of the gills was the main pathology found, detected in both species but predominant in the $N$. coriiceps. Hyperplasia may be a typical defense mechanism which works by increasing the diffusal distance between the polluents and the blood flow, causing hindrance to gas exchanges (Dutta et al., 1993; Karan et al., 1998).

\section{Conclusion}

Liver and branchial alterations reported in this study are not specific of one harmful agent, with the possibility of being a result of physiological mechanisms or many types of physical, chemical and biological agents of Admiralty
Bay. From the data analyzed, it can be concluded that the functionality of the analyzed organs was not affected and thus, may not be classified as lethal to the species under investigation

\section{Acknowledgements}

This work integrates the National Institute of Science and Technology Antarctic Environmental Research (INCTAPA) that receive scientific and financial supports of the National Council for Research and Development (CNPq process: $n^{\circ} 574018 / 2008-5$; and process: $n^{\circ} 52.0125 / 2008-8$ ) and Research Support Foundation of the State of Rio de Janeiro (FAPERJ nº E-16/170.023/2008). The authors also acknowledge the support of the Brazilian Ministries of Science, Technology and Innovation (MCTI), of Environment (MMA), and Inter-Ministry Commission for Resource of the Sea (CIRM) and PQ for L. Donatti nr. 305562/2009-6.

\section{References}

Bernet, D.; Schmidt, H.; Meier, W.; Burkhardt-Holm, P. \& Wahli, T. (1999). Histopathology in fish: proposal for a protocol to assess aquatic pollution. Journal of Fish Diseases, 22: 25-34.

Bícego, M.C.; Weber, R.R. \& Ito, R.G. (1996). Aromatic hydrocarbons on surface waters of Admiralty bay, King George Island, Antarctica. Marine Pollution Bulletin, 32:549-53.

Brasileiro-Filho, G. (1994). Bogliolo Patologia. 5. ed. Rio de Janeiro: Guanabara Koogan.

Clark, G. (1981). Staining procedures. Baltimore: Willians \& Wilkins.

Dutta, H. M.; Richmonds, C. R. \& Zeno, T. (1993). Effects of Diazinon on the bluegill sunfish Lepomins macrochirus. Journal of Environmental Pathology, 12 (4): 219-27.

Karan, V.; Vitorović, S.; Tutundžić, V. \& Poleksić, V. (1998). Functional enzymes activity and gill histology of carp after copper sulfate exposure and recovery. Ecotoxicology and Environmental Safety, B-40: 49-55.

Karnovsky, M.J. (1965). A formaldehyde-glutaraldehyde fixative of high osmolality for use in electron microscopy. Journal of Cell Biology, 27: 137-8.

Mallat, J. (1985), Fish gill structural changes induced by toxicants and others irritants: A statistical review. Canadian Journal of Fishes Aquatic Science, 42: 630-48.

Martins, C.C; Rose, M.C.B.; Taniguchi, S.; Lourenço, R.A; Figueira, R.C.L.; Mahiques, M.M. \& Montone, R.C. (2010). Historical Record of polycyclic aromatic hydrocarbons (PAHs) and spheroidal carbonaceous particles (SCPs) in marine sediment cores from Admiralty Bay, King George Island, Antarctica. Environmental Pollution, 158: 192-200.

Myers, M.S. \& Fournie, J.W. (2002). Histophatological biomarkers as integrators of anthropogenic and environmental stressors. In: Adams, S.M. Biological indicators of aquatic ecosystem stress. American Fisheries Society: Bethesda, MD. 
Montone, R.C.; Martins, C.C.; Bícego, M.C.; Taniguchi, S.; Silva, D.A.M.; Campos, L.S. \& Weber, R.R. (2010). Distribution of sewage input in marine sediments around a maritime Antarctic research station indicated by molecular geochemical indicators. Science of the Total Environment, 408: 4665-71

Ngan, P. V.; Gomes, V.; Passos, M.J.A.C.R.; Ussami, K.A.; Campos, D. Y. F.; Rocha, A. J. S. \& Pereira, B.A. (2007). Biomonitoring of the genotoxic potential (micronucleus and erythrocyte nuclear abnormalities assay) of the Admiralty Bay water surrounding the Brazilian Antarctic Research Station "Comandante Ferraz", King George Island. Polar Biology, 30: 209-17.

Oliveira, L.M.; Mendonça, E.S.; Jham, G.; Schaefer, C.E.G.R.; Silva, I.R. \& Albuquerque, M.A. (2007). Hidrocarbonetos em solos e sedimentos do entorno da Estação Antártica Brasileira Comandante Ferraz. Oecologia Brasiliensis 11 (1): 144-156.

Roberts, R.J. (1989). Fish Pathology. 2nd. ed. London: Baillière Tindall.

Santos, A.A.; Ranzani-Paiva, M.J.T.; Felizardo, N.N. \& Rodrigues, E.L. (2006). Análise histopatológica de fígado de tilápiado-nilo, Oreochromis niloticus, criada em tanque-rede na represa de Guarapiranga, São Paulo, SP, Brasil.

Thophon, S.; Kruatrachue, M.; Upatham, E.S.; Pokethitiyook, P.; Sahaphong, S. \& Jaritkhuan, S. (2003). Histopathological alterations of white seabass, Lates calcarifer, in acute and subchronic cadmium exposure. Environmental Pollution, 121:307-20

Tin, T.; Fleming, Z.L.; Hughes, K.A.; Ainley, D.G.; Convey, P.; Moreno, C.A.; Pfeiffer, S.; Scott, J. \& Snape, I. (2008). Impacts of local human activities on the Antarctic environment. Antarctic Science 21: 3-33.

Van Den Heuvel, M.R.; Power, M.; Richards, J.; Mackinnon, M. \& Dixon, D.G. (2000). Disease and gill lesions in Yellow Perch (Perca flavescens) exposed to oil sands mining-associated waters. Ecotoxicology and Environmental Safety, B-46: 334-41.

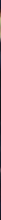

